\title{
Nitrogen Gas Solubility in Molten Sodium Nitrate-Potassium Nitrate Mixture
}

\author{
Kazutaka KawAmURA*, Yoshihisa Teramoto** and Yoshiaki SUzUki***
}

\begin{abstract}
The nitrogen gas solubility over the entire concentration range of molten sodium nitrate-potassium nitrate mixture has been measured by an elution method at 543,593 , and $643 \mathrm{~K}$. The obtained values of solubility, $K_{\mathrm{p}}$, are found to be in the range from $1.5 \times 10^{-7}$ to $3.4 \times 10^{-7} \mathrm{~mol} \mathrm{~cm}^{-3} \mathrm{~atm}^{-1}$. The enthalpy change for solution of nitrogen gas in this mixture shows the positive value, indicating the endothermic reaction. By comparing the calculated value of $K_{\mathrm{p}}$ with the experimental value, the concentration dependence of $K_{\mathrm{p}}$ could be explained.
\end{abstract}

\section{Introduction}

Many data have been reported on gas solubilities in pure molten salt but only a few data on gas solubilities in a limited range of molten salt mixture, i.e., an eutectic mixture, and few experiments have been carried out in the entire range of molten salt mixture ${ }^{1)}$. Generally, the gases dissolving in molten salt are divided into two classes"); a) non-polar gas such as $\mathrm{He}, \mathrm{Ne}$, Ar and perhaps $\mathrm{N}_{2}, \mathrm{O}_{2}, \mathrm{Cl}_{2}$, and $\mathrm{CO}_{2}$, b) polar gas such as $\mathrm{HF}, \mathrm{DF}, \mathrm{H}_{2} \mathrm{O}, \mathrm{BF}_{3}$, and $\mathrm{NH}_{3}$. According to another classification the gases belong to one of the following two classes; a) inert gas such as $\mathrm{He}, \mathrm{Ne}, \mathrm{Ar}$, and $\mathrm{N}_{2}$, b) reactive gas such as halogens, $\mathrm{CO}_{2}, \mathrm{SO}_{2}, \mathrm{HF}$, $\mathrm{HCl}, \mathrm{TiCl}_{4}$, and $\mathrm{NbCl}_{5}$.

In addition to that there is no published data on the nitrogen gas solubilities over the entire range of sodium nitrate-potassium nitrate mixture, another motivation for investigating this system arises from the hope in examining how the solubilities of non-polar or inert gas such as nitrogen vary with the concentration of one component in mixture. Comparing the experimentally obtained nitrogen solubility with the calculated one in molten sodium nitrate-potassium

* Research Laboratory for Nuclear Reactors Tokyo Institute of Technology (2-12-1, Ookayama, Meguroku, Tokyo)

** New Tokyo International Airport, Aviation Weather Service, Japan Meteorological Agency (133, Komemae, Furugome, Narita, Chiba)

*** Tochigi Plant, Bridgestone-Bekaert Steel Cord Company (800, Chimonakano, Kuroiso, Tochigi)

Key Words: Nitrogen Gas Solubility, Molten Alkali Nitrate, Endothermic Reaction, Elution Technique nitrate mixture, one can make it possible to elucidate the behaviour of dissolved nitrogen gas molecule in molten salt.

\section{Experimental}

Experimental techniques can be categorized into following three classes ${ }^{23}$; a) absorption method, where the solubility is determined by means of observing the volumetric or manometric change in the solute or the gravimetric change in the solvent, b) elution method, where the solubility is determined from the quantity of gas stripped from a saturated solution, c) cryometric method, where the solubility is determined from the freezing point depression of the solvent. In this paper, elution technique was used for the determination of nitrogen gas solubility.

Materials ; Reagent grade sodium nitrate and potassium nitrate were mixed and dried in an oven at $423 \mathrm{~K}$ for a week. Then the dried salts were transferred to the experimental cell and dessicated under vacuum just below the melting point for a half or one day. Nitrogen and helium gases were obtained in cylinders and nominal purities of both nitrogen and helium gases were $99.9989 \%$ and $99.998 \%$, respectively.

Apparatus; The apparatus used in this work was almost identical with that developed by Grimes $^{3)}$ as shown in Fig. 1. It consists of gas saturating and elution vessels which are connected in series with a $0.8 \mathrm{~cm}$ i.d. tube. All the vessel are made of 304 stainless steel. The sizes of both cylindrical saturating and elution vessels were $12.6 \mathrm{~cm}$ in diameter and $40.1 \mathrm{~cm}$ in length. 


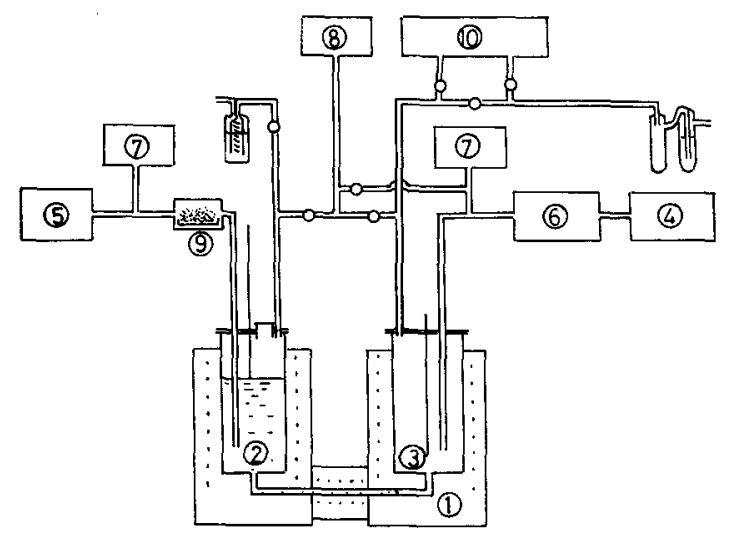

Fig. 1 Schematic diagram of apparatus for determination of nitrogen gas solubility in molten sodium nitratepotassium nitrate mixture

1 : Electric furnace, $6:$ He gas purifier

2 : Saturation vessel, $7:$ Manometer

3 : Elution vessel, 8 : Vacuum pump

$4: \mathrm{He}$ gas supply, $9: \mathrm{P}_{2} \mathrm{O}_{5}$ desiccant

$5: \mathrm{N}_{2}$ gas supply, $10:$ Gas chromatography

The vessels are located in large resistance furnace and the lid of vessel is provided with gas inlet tube, gas outlet tube, and thermocouple well.

Procedure; A $6 \mathrm{~kg}$ charge of salt was placed in the saturating vessel. Bubbling of nitrogen gas in saturation vessel was achieved by heating the salt at the desired temperature and was carried out for $4 \mathrm{~h}$. Thereafter, the saturated molten alkali nitrate was transferred to the elution vessel through the connecting tube by heating the frozen seal of salt and helium gas was bubbled through the melt in elution vessel in order to remove the dissolved nitrogen gas in melt. The stripped nitrogen gas was analyzed quantitatively by means of gas chromatography.

\section{Results and Discussion}

The pressure dependence of the solubility in the limit of low solubility is given by the Henry's law constant $k_{\mathrm{H}}$,

$$
P_{\mathrm{g}}=k_{\mathrm{H}} X_{\mathrm{d}}
$$

where $X_{\mathrm{d}}$ is the mole fraction of the solute gas in melt and $P_{\mathrm{g}}$ is the gas pressure expressed in atm. When Henry's law is experimentally verified, the pressure dependence of the solubility has typically given by the following modified form,

$$
K_{\mathrm{p}}=\mathrm{C}_{\mathrm{d}} / P_{\mathrm{g}}
$$

where $C_{\mathrm{d}}$, expressed in $\mathrm{mol} \mathrm{cm}{ }^{-3}$ salt, is the concentration of gas in molten salt and $K_{\mathrm{p}}$ is related to $k_{\mathrm{H}}$ on the approximation that the partial volume of the molten salt, $\bar{V}$ expressed in $\mathrm{cm}^{3} \mathrm{~mol}^{-1}$ gas, is constant over the pressure range for which Henry's law is obeyed" ${ }^{1}$.

$$
K_{\mathrm{p}}=1 /\left(k_{\mathrm{H}} \bar{V}\right)
$$

Since the majority of solubilities have been found to obey Henry's law, the equilibrium constant or pressure independent solubility, $K_{p}$ expressed in $\mathrm{mol} \mathrm{cm}^{-3} \mathrm{~atm}^{-1}$, is the most com-

\begin{tabular}{|c|c|c|c|c|c|}
\hline $\begin{array}{l}\mathrm{KNO}_{3} \text { concentration } \\
\text { mol per cent }\end{array}$ & $\begin{array}{c}\text { Temperature } \\
\mathbf{K}\end{array}$ & 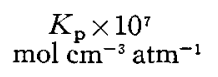 & $\underset{\mathrm{kcal} \mathrm{mol}^{-1}}{\triangle H}$ & $\begin{array}{c}K_{\mathrm{pcyl} 1} \times 10^{7} \\
\mathrm{~mol} \mathrm{~cm}^{-3} \mathrm{~atm}^{-1}\end{array}$ & $\begin{array}{c}K_{\mathrm{psph}} \times 10^{7} \\
\mathrm{~mol} \mathrm{~cm}^{-3} \mathrm{~atm}^{-1}\end{array}$ \\
\hline \multirow[t]{2}{*}{0} & 593 & $2.5 \pm 0.20$ & $4.7 \pm 2.0$ & 0.77 & 0.11 \\
\hline & 643 & $3.4 \pm 0.30$ & $\begin{array}{l}(2.74 \pm 0.83) \\
(3.96 \pm 2.2)\end{array}$ & 1.26 & 0.23 \\
\hline \multirow[t]{2}{*}{25} & 593 & $2.0 \pm 0.12$ & $4.0 \pm 1.8$ & 0.84 & 0.13 \\
\hline & 643 & $2.6 \pm 0.20$ & & 1.36 & 0.26 \\
\hline \multirow[t]{3}{*}{50} & 543 & $1.8 \pm 0.12$ & $2.0 \pm 0.6$ & 0.49 & 0.06 \\
\hline & 593 & $2.1 \pm 0.12$ & $(4.07 \pm 0.23)$ & 0.90 & 0.14 \\
\hline & 643 & $2.4 \pm 0.12$ & & 1.48 & 0.28 \\
\hline 66 & 593 & $1.5 \pm 0.12$ & & 0.92 & 0.15 \\
\hline \multirow{2}{*}{75} & 593 & $1.7 \pm 0.10$ & $2.5 \pm 1.0$ & 0.94 & 0.15 \\
\hline & 643 & $2.0 \pm 0.10$ & & 1.56 & 0.30 \\
\hline$(100)$ & $(670)$ & $(2.93)$ & $(1.72 \pm 0.78)$ & 1.61 & 0.32 \\
\hline
\end{tabular}
monly reported quantity ${ }^{1}$.

Table 1 Nitrogen gas solubilities in molten sodium nitrate-potassium nitrate mixtures

Values in parenthesis were taken from the solubility data reported in ref, 4,2,5 and 1 
The values of $K_{\mathrm{p}}$ of nitrogen gas over the entire range of sodium nitrate-potassium nitrate mixture at various temperatures are summarized in Table 1. The accuracies indicated are based on the assumption that three sources of error, i.e., the uncertainties in peak area of integrated gas chromatogram, the determination of volume for molten alkali nitrate mixture, and temperature reading, are involved. These errors lead to an average uncertainty $6-10 \%$ in the calculated values of $K_{\mathrm{p}}$.

Although experimental errors are sizable, some tenuous comparisons and conclusions could be still made. The concentration dependencies of $K_{\mathrm{p}}$ are shown in Fig. 2 over the entire range

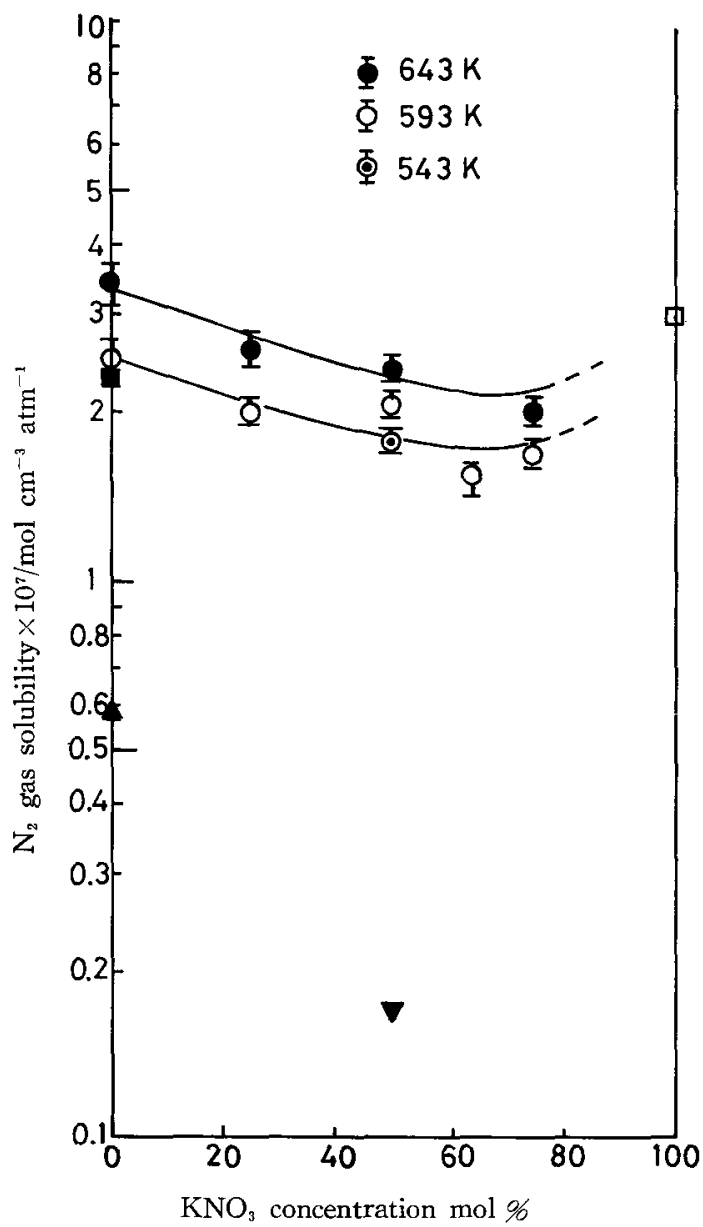

Fig. 2 Variations of $K_{\mathrm{p}}$ with $\mathrm{KNO}_{3}$ concentration at 543, 593, and $643 \mathrm{~K}$

$670 \mathrm{~K}$ taken from ref. 1), $640 \mathrm{~K}$ taken from ref. 2), $\Delta 640 \mathrm{~K}$ taken from ref. 4), $\nabla 640 \mathrm{~K}$ taken from ref. 5) of composition for potassium nitrate, together with the other published date ${ }^{1,2,45}$. It seems that some values of $K_{\mathrm{p}}$ obtained by other workers, i.e., a value of $K_{\mathrm{p}}$ for pure sodium nitrate and a value of $K_{\mathrm{p}}$ for eutectic mixture, are different from those in this work. At first sight of present work in Fig. 2, however, $K_{\mathrm{p}}$ decreases with increasing potassium nitrate until the concentration of potassium nitrate is reached to about $60 \mathrm{~mol} \%$ and then increases with increasing potassium nitrate.

The enthalpy of solution of gas in molten salt, $\triangle H$ expressed in $\mathrm{kcal} \mathrm{mol}^{-1}$, is calculated from the relationship;

$$
\frac{\mathrm{d} \ln K_{\mathrm{p}}}{\mathrm{d}\left(\frac{1}{T}\right)}=-\frac{\Delta H}{R}
$$

where $R$ is an usual gas constant. The obtained values of $\Delta H$ listed in Table 1 with positive values $^{2)}$ show an endothermic enthalpy change for solution. The values for $\Delta H$ obtained from other workers ${ }^{1,2,4,5)}$ are also included in parenthesis in Table 1 for the purpose of comparison with our data. The agreement between them is good within an experimental error except that for $50 \mathrm{~mol}$ \% eutectic mixture ${ }^{5)}$, Apart from the value of $\triangle H$ obtained by Paniccia and Zambonin $^{5)}$, it seems that the values of $\triangle H$ decrease with increasing potassium nitrate concentration*1.

The basic calculating method for expressing the gas solubility in molten salt has been derived by Blander et $a l^{i}$, who modified the Uhlig model ${ }^{\text {") }}$ on gas solubility in non-ionic solvent. According to this model, the gas solubility in molten salt can be calculated from the surface free energy of formation of the cavity created by the solute molecule ${ }^{2)}$. The equation is expressed in terms of $K_{\mathrm{p}}$;

$$
-\ln \left(K_{\mathrm{p}} \cdot R T\right)=\frac{A_{r}}{k T}
$$

where $k$ is the usual Boltzmann constant, $A$ is the surface area of the cavity taken as equal to the surface area of the solute molecule, and $r$ is the "microscopic" surface tension of molten

*1 Although the entropy change for solution, $\triangle S$, is also calculable, we want to have no further discussion on $\triangle S$ because the uncertainty in $\triangle S$ comes from the limited number of experiment and sizable experimental error of $K_{\mathrm{p}}$ produces some ambiguity. 
salt assumed to be equal to the "macroscopic" surface tension. In the case of linear polyatomic molecule such as $\mathrm{N}_{2}$, two alternative values of $A$ are possible ${ }^{2}$. When the molecule is assumed to be freely rotating, the cavity surface area is equal to the spherical region swept out by the radius. When the molecule is assumed to be nonrotating, the cavity surface area would be equal to that of cylinder having hemispherical ends. The values of $A$ for rotating and nonrotating nitrogen molecules are $51.8 \mathrm{~A}^{2}$ and 3816 $A^{2}$, respectively ${ }^{2}$.

The calculated values of $K_{\mathrm{p}}$ are also listed in Table 1. It is shown from this table that the calculated values of $K_{\mathrm{pcyl}}$ for nonrotating molecules are larger than the calculated values of $K_{\mathrm{psph}}$ for rotating molecules. Qualitatively it is apparent that the calculated values of $K_{\mathrm{pcyl}}$ are more agreeable with the experimental $K_{\mathrm{p}}$ values than the values of $K_{\mathrm{psph}}$. However, one possible explanation for the curve of concentration dependence of nitrogen gas solubility with a minimum value is that the nitrogen molecules may be regarded as nonrotating molecules in molten salt in excess of sodium nitrate or potassium nitrate and, on the other hand, as rotating molecules in eutectic or nearly eutectic mixture at 543,593 , and $643 \mathrm{~K}$. This is not surprising when one takes notice of the higher melting point of alkali nitrate in excess of sodium nitrate or potassium nitrate than that of eutectic or nearly eutectic mixture. At present, no further information can be gleaned from the present results.

\section{Acknowledgement :}

The authers wish to thank the Ministry of Education for Grant-in-Aid for fusion research in support of this work. They are also grateful to Dr. Yoshida for his assistance in the design and the making of present apparatus.

\section{References:}

1) J. Braunstein, G. Mamantov and G.P. Smith, (e. d.) "Advances in Molten Salt Chemistry", Vol. 3 p. 75 (1975), Plenum Press, New York.

2) P.E. Field and W.J. Green, J. Phys. Chem. 75, 821 (1971).

3) W.R. Grimes, N.V. Smith and G.M. Watson, $J$. Phys. Chem. 62, 862 (1958).

4) B. Cleaver and D.E. Mather, Trans. Faraday Soc. 66, 2469 (1970).

5) F. Paniccia and P.G. Zambonin, J. Chem. Soc. Faraday Trans. Part 1 68, 2083 (1972).

6) M. Blander, W.R. Grimes, N.V. Smith and G.M. Watson, J. Phy's. Chem. 63, 1164 (1959).

7) H.H. Uhlig, J. Phys. Chem. 41, 1215 (1937).

(Received Aug. 26, 1981 ; Accepted Oct. 28, 1981)

\section{応用電気化学の文献紹介（5)}

Investigation of Laser-Enhanced Electroplating Mechanisms, J. Cl. Puippe, êt al., J. Electrochem. Soc. 128, 2539 (1981).

電析においてレーザーを電極に照射したとき析出速 度が大幅に上昇する現象の機構と灾用について検討し た.レーザーの波長を溶液の吸収がない領域に選定し てやるとレーザーのエネルギ一は金属・溶液界面のみ 吸収されて局部的な温度上昇を引きおこす，その結果， 部分的に電何移動過程が促進されることと同時に生し る熱対流により物質移動過程が促進されるとい52つ の理由により反応速度の上昇を説明している。また温 度上昇に伴ら自然電位の局所的変動により局部電池が 形成されるために照射部分に無電解メッキをすること ができることを示している。このような方法により微 細なメッキ加工を行なえることからエレクトロニクス
工業への応用が期待できる.

Electrodeposition of Silicon from Solutions of Silicon Halides in Aprotic Solvents, A.K. Agrawal and A.E. Austin, J. Electroch̆em. Soc. 128, 2292 (1981).

太陽電池の実用化に伴ってアモルファスシリコン薄 膜の製造コストダウンが重要な問題になっているが, ここでは従来の気相成長法に替るものとして液相中電 気化学的にシリコンを析出させる方法を試みている. プロピレンカーボネートに良く溶ける $\mathrm{SiHCl}_{3}$ を用い て導電率を上げるために $0.1 \mathrm{M}$ のテトラブチルアン モニウムクロライドを支持塩として加えた浴を使用し ている．析出したシりコン中に注水素怔少量念まれて いたが，これは浴の組成を変えることによりコントロ ールできる。

(職業訓練大学校 青柿良一) 